\title{
The Sundanese Head Tie as a Sundanese Political Brand Identity in Indonesia(Biographical Study of Dedi Mulyadi's Politicians 2003-2018)
}

\author{
Rina Nurhayati, Engkus Kuswarno, Neni Yulianita
}

\begin{abstract}
Brand identity is usually claimed on a product, even though an individual is primarily a public figure who needs his own identity so that it is in the minds of the community or its supporters, so the writer limits the research focus to the "Iket Sunda" (Sundanese headband) used by Dedi Mulyadi as a politician who succeeded in building a lead in Purwakarta Regency in West Java, Indonesia, from a city that passively became a city that was active in the community and crowded. While the purpose of this study was to find out the Brand Identity of Politicians Dedi Mulyadi through the Sundanese Typical Head Tie.

This study uses a qualitative method with a biographical study approach, a factual description of social phenomena through a constructivist paradigm.

The results of this study that the author found were two aspects that did not yet exist in Kapferer's The Six Facets Prism Brand Identity, namely the Standard and Professional aspects as forming the Eight Facets Prism - Political Brand Identity. Called Octagon of Political Brand Identity.

There are findings of novelty research results. The research on this biography study is still fairly rare, so it is original, originating from the main subject, Dedi Mulyadi and validated by living witnesses and material from trusted online media coverage in Indonesia and so that they can add reference to the field of communication, especially in the narrative study approach.
\end{abstract}

Keywords: Iket Sunda, Dedi Mulyadi, Octagon of Political Brand Identity

\section{INTRODUCTION}

Choosing 1 (one) of many politicians to be appointed to the Biography Study of this research, is quite interesting. Apart from various aspects of the election, there are interesting things related to followers on social media as one of the choices. The figure of Dedi Mulyadi has a number of followers of more than 10 million, this is stated in one of the Online Papers "Suara Indonesia" (1).

Dedi Mulyadi is a regional leader who is different from other regional leaders. As a public figure, Dedi Mulyadi distinguishes himself, both through speech, attitude and fashion. One of the differentiations is through a part of the traditional fashion or attribute that is often used by Dedi Mulyadi, namely the head tie of Sundanese or Sundanese

Revised Manuscript Received on April 19, 2019.

Rina Nurhayati, Faculty Of Communication, Padjadjaran Bandung University, Bandung, 45363, Indonesia

Engkus Kuswarno, Faculty Of Communication, Padjadjaran Bandung University, Bandung, 45363, Indonesia

Neni Yulianita, Faculty of Communication, Bandung Islamic University, Bandung, 40116, Indonesia
Iket (same with Iket Sunda). Dedi Mulyadi is one of the original Sundanese politicians born in Subang, West Java province - Indonesia. He was once destined to lead Purwakarta Regency for 3 Periods, became deputy Regent 1 period (2003 - 2008), served as Regent 2 periods (2008 2018), and while leading Purwakarta Regency, Dedi Mulyadi could not be separated from the use of Sundanese head tie or Sundanese Iket in formal and non-formal activities. "Increasing use of head or Sundanese cribs. Not only old people, young people are no less lively using Sundanese Iket. Even for them Sundanese Iket is made a fashion. Even though it is used in addition to being used on the head, sometimes they like to wrap it in their hands or throw it in the neck" (2).

Based on information obtained from living witnesses who have known Dedi Mulyadi since becoming member of the level II People's Representative Council in Purwakarta in 2000, Mochamad Rafe'i - Former Regional Assistant I for Government Affairs, Kab. Purwakarta (2005 - 2009 period) said that : "Mr. Dedi Mulyadi has used Iket Sunda since being elected as the Deputy Regent of Purwakarta around 2003. Sundanese head tie are always used both when not official and used during official activities. He is not ashamed to use Sundanese Iket when working" (3).

In various online news with different links it can be found that Dedi Mulyadi is a trend setter in the use of Sundanese Iket, this can be seen in the following table.1: 
International Conference on Recents Advancements in Engineering and Technology (ICRAET-18) |15th and 16th March 2019|Siddhartha Institute of Technology \& Sciences, Telangana, India.

Table.I

Dedi Mulyadi as the Pioneer of Sundanese Iket

\begin{tabular}{|c|c|c|}
\hline $\mathrm{NO}$ & LINK & NARRATIVE \\
\hline 1 & $\begin{array}{l}\text { https://www.liputan6.com/news/read/2967 } \\
\text { 385/ribuan-bedug-dan-petromak-sambut- } \\
\text { ramadhan-di-purwakarta }\end{array}$ & $\begin{array}{c}\text { Men who are the pioneers of the use of Sundanese Iket at this } \\
\text { official event also have their own hopes in this year's Ramadan } \\
\text { (4). }\end{array}$ \\
\hline 2 & $\begin{array}{l}\text { https://www.merdeka.com/peristiwa/tiga- } \\
\text { hal-ini-jadi-refleksi-bupati-dedi-mulyadi-di- } \\
\text { gua-hira.html }\end{array}$ & $\begin{array}{c}\text { As is known, the pioneers of the use of Sundanese Iket in this } \\
\text { official event were carrying out umrah in the Holy Land of } \\
\text { Mecca with their families and teachers (5). }\end{array}$ \\
\hline 3 & $\begin{array}{l}\text { https://regional.kompas.com/read/2018/07/ } \\
\text { 17/15164821/melihat-gaya-pakaian-dedi- } \\
\text { mulyadi-dan-sikapnya-yang-anti-protokoler }\end{array}$ & $\begin{array}{c}\text { In addition, his Sundanese white Iket has become a distinctive } \\
\text { feature since he served as deputy regent of Purwakarta in } 2003 \\
\text { (6). }\end{array}$ \\
\hline 4 & $\begin{array}{l}\text { https://news.detik.com/berita/3077205/dibe } \\
\text { ri-iket-oleh-bupati-purwakarta-anna-karina- } \\
\text { dari-filipina-its-cool }\end{array}$ & $\begin{array}{c}\text { "Wow, it's cool," said Anna Karina Jardin, from the } \\
\text { Philippines when she was directly paired with Sundanese Iket } \\
\text { by Dedi on the sidelines of the 1st ASEAN Entrepreneurship } \\
\text { Summit at Prince Court Hospital, Kuala Lumpur, Malaysia, } \\
\text { Saturday (11/21/2015). Anna is the owner of Artisanong } \\
\text { Kaabatan, an NGO that works to build the leadership of young } \\
\text { Filipinos with cultural channels (7). }\end{array}$ \\
\hline 5 & $\begin{array}{l}\text { https://www.merdeka.com/peristiwa/makn } \\
\text { a-di-balik-setelan-pangsi-dedi-mulyadi.html }\end{array}$ & $\begin{array}{l}\text { Kang Dedi also has characteristics. That is the way he is } \\
\text { dressed. He always used Sundanese traditional clothes, in the } \\
\text { form of clothes and pangsi pants, and never abandoned } \\
\text { Sundanese Iket. The clothes continue to be used for work every } \\
\text { day. "Pangsi is a loose shirt. A mirror of openness and broad } \\
\text { movements. While Iket Sunda is an attachment of mind by } \\
\text { hear.." (8). }\end{array}$ \\
\hline 6 & $\begin{array}{l}\text { http://jabarekspres.com/2018/kampret- } \\
\text { kang-dedi-paling-laku/ }\end{array}$ & $\begin{array}{c}\text { Clothing worn by Dedi Mulyadi since he was still serving as } \\
\text { Deputy Bupati Purwakarta until now is indeed often a fashion } \\
\text { reference (9). }\end{array}$ \\
\hline 7 & $\begin{array}{l}\text { http://www.rmoljabar.com/read/2015/04/1 } \\
\text { 9/8347/Berkat-Dedi-Mulyadi-Busana-Sunda- } \\
\text { jadi-Fashion-Trendsetter- }\end{array}$ & $\begin{array}{l}\text { Today the dipper is welcomed. The seeds are delayed with the } \\
\text { Sundanese clothes that Kang Dedi planted like spring in the } \\
\text { spring. Now the world seems to follow Kang Dedi's madness. } \\
\text { Sundanese clothing complete with Sundanese Iket on the head is } \\
\text { now appreciated in all places as an icon for pulling a timeline } \\
\text { (10). }\end{array}$ \\
\hline
\end{tabular}

\section{Source: Processed by the author, 2019}

Opinions aside from online media, said : Dian Anggraeni Umar, Executive Director \& Communication Strategist Holistic Reputation Advisory when asked about the appearance of Dedi Mulyadi : "His appearance is unique and creates a distinctive identity about the figure of Dedi Mulyadi. By using pangsi and Sundanese Iket as the Cepot (Sundanese puppet). He wanted to be seen as an eccentric and very Sundanese official. But this is good for selfvisualization so the public can more easily recognize and identify Dedi Mulyadi” (11).

Iket Sunda or Sundanese Iket is part of Dedi Mulyadi's daily fashion, as the essence of nonverbal communication. Through fashion, as if Dedi Mulyadi wanted to convey a deep message, because Sundanese Iket used in his head was not only limited to the fabric of binding, but there was a good meaning or noble philosophy. Malcolm Bernard in Fashion Statements: "Communication And Culture stated that ; Fashion has been established as being meaningful and as communicative. It has also been established as a profoundly cultural entity" (12), and although the appearance in dressing and its attributes cannot transfer messages directly, but has deep meaning, many meanings or meaningfull as expressions of mental images.
Previous research used as a research gap with the similarity of the title, namely the political brand identity and method, but different from the paradigm, research approach, and location of research is the result of research by Christopher Pich, Dianne Dean \& Khanyapuss Punjaisri entitled ; Political brand identity : An examination of the complexities of Conservative brand and internal market engagement during the 2010 UK General Election campaign ; which explores members of the British Conservative Party's attitude towards Conservative brand development as personified by David Cameron. There are clear implications for political strategists as shown by the finding that it is very important to involve internal markets in the communication strategy marketing creations (13). Researchers feel the need to raise the issue of cultural attributes through the typical head tie symbol of Sundanese or Sundanese Iket into a research study.

The focus of this research is on identifying the problem, namely; How can Sundanese iket become the political brand identity of Dedy Mulyadi ?, and the purpose of this

\section{Published By:}

Blue Eyes Intelligence Engineering

\& Sciences Publication 
study was to find out Sundanese Head Tie (Iket Sunda) as the political brand identity of Dedi Mulyadi. Theoretically it is expected that it will contribute to the study of communication actors through biographical studies that are still rare in the field of Communication Sciences.

\section{LITERATURE REVIEW}

\section{A. Iket Sunda (Sundanese Head Tie)}

In one of the online media articles of Pikiran Rakyat, according to Deddy Mulyana : Clothing and accessories such as suits, headscarves, caps, and headbands are symbolic. Symbols may imply religion, ideology, culture, beliefs, social status, personal identity, personality, for convenience, although it can also be for imaging, entertainment, or just fad ... headbands are a symbol of Sundanese cultural revival, especially its constructive aspects (14).

The Sunda Iket Community or KIS about Iket Sunda states that headband : (is) Product or Object Used in the Head Area with Specific Functions. The meaning of the Sundanese icon has 2 things, namely as a function and philosophy. Functions : 1. Protecting the Head from Weather 2. Adding Appearance Aesthetics 3. SelfExpression and Identity. Philosophy: Binding Your Self Lust. Sundanese Iket Function: a. Practical Function In ordinary society, besides functioning to cover the hair and protect the head, it also functions as a weapon to defend itself if an attack suddenly occurs. Besides that it serves as a tool for storing and carrying items. b. Aesthetic Functions Besides being able to protect the head, iket can enhance the appearance of men and become a complementary element of dress that suits men. c. Symbolic Functions Symbolic values for iket for example there are several types of iket forms which are only used for certain people or certain occasions. Basic Definition; The Sundanese Iket philosophy "binds one's self-desire to be a good human being". Iket is one of the aesthetic representations of the Sundanese culture in which the values of philosophy are contained, namely about equality; divinity and the value of truth ". "The meaning in the rectangular shape of the etiquette is a 4-way reflection; North, South, West, East; folded into a triangle containing meaning : Ucap (Words) - Tekad (Attitude) - Lampah (Step), must be in one bond (One Harmony). Three Stages of Iket Philosophy; Kataji (Interested) - Kasungsi (Using) - Kaharti (Understanding the Meaning of Philosophy); this stage is achieved by the person of each user ". Distribution of Types Based on How to Use, the stages of usage are divided into 3 types ; 1). Lepasan or Gebaran Amparan, this type of iket amparan is a piece of cloth in the form of a square, triangle or square (the shape of a scarf) which is folded, wrapped and then tied to the head, with a certain skill process; 2). Practical Iket (Iket Panganteur), A form of Sundanese iket that has been sewn so that it does not require knowledge on how to tie it on the head; like cap or hat; easy to use; 3). Practical Iket Teungukur, Same with the practical type of Panganteur cricket, coupled with a changeable system of head circumference, using "fastener tape" (velcro or perepet) or using rubber so that various head sizes can be used. Distribution of Types Based on the Form or Shape of
Sundanese Iket : 1) Rupa Iket Bihari or the past or iket kampung adat still used and maintained by the Sundanese traditional village community, 2). Rupa Iket Rekaan Kiwari or the present The creation of the type of iket, only started around the beginning of 2000, 3). Iket Praktis (Iket Panganteur), The creation of this kind of practical iket began with the traditional village in Kuningan Cigugur (Barangbang semplak cigugur), This icon is sewn so that the wearer just wears it practically, 4). Iket Wanoja. It Is A Deserving Icon For Use By Women; Feminine form. Started to be introduced in 2011 by Komunitas Iket Sunda. The Shape Of This Icon Is Originally Formed From A Shawl, And Is Now In Development To Introduce Iket Wanoja By Using Iket Fabrics Commonly Used By Men, 5). Iket Kolaborasi (Rekarupa), It is a form of Iket that is modified due to special needs such as for performances, inclusion of certain symbols or logos, blend of functions or characteristics of other products (15).

\section{B. Brand Identity}

According to the American Marketing Association (AMA), a brand is a "name, term, sign, symbol, or design, or a combination of them, intended to identify the goods and services of one seller or group of sellers and to differentiate them from those of competition" (16). According to Kapferer ; A brand is not the name of a product. It is the vision that drives the creation of products and services under that name. That vision, the key belief of the brands and its core values is called identity. It drives vibrant brands able to create advocates, a real cult and loyalty (17).

According to Kapferer in his book, New Strategic Brand Management $(182-186)$; there are six facets prism that are depicted in hexagonal form ; 1). A brand, first of all, has physical specificities and qualities - its 'physique. Physique is both the brand's backbone and its tangible added value, 2). A brand has a personality. By communicating, it gradually builds up character. The way in which it speaks of its products or services shows what kind of person it would be if it were human, 3). A brand is a culture. There is no cult brand without a brand culture. A brand should have its own culture, from which every product derives. The product is not only a concrete representation of this culture, but also a means of communication, 4). A brand is a relationship. Indeed, brands are often at the crux of transactions and exchanges between people, 5). A brand is a customer reflection. Because its communication and its most striking products build up over time, a brand will always tend to build a reflection or an image of the buyer or user which it seems to be addressing Reflection and target often get mixed up. The target describes the brand's potential purchasers or users. Reflecting the customer is not describing the target; rather, the customer should be reflected as he/she wishes to be seen as a result of using a brand, 6). A brand speaks to our self-image. If reflection is the target's outward mirror (they are ...), self-image is the target's own internal mirror (I feel, I am ...). Through our

\section{Published By:}


attitude towards certain brands, we indeed develop a certain type of inner relationship with ourselves (17).

\section{RESEARCH METHOD}

Paradigm. In this study using a constructivist paradigm, considering that humans are dynamic, creative creatures. Humans as social beings with a set of provisions given by God, namely; reason, heart, desire and interest to show self existence through symbols, to convey about who he is, so that people can easily know him. Analysis of the reality of life is done through scientific steps and methods. Many aspects of constructions are frequently shared between individuals who hold similar values or beliefs, or who, for a variety of reasons (think again of class, race, gender, sexual orientation, political leanings, religious upbringing, and the like), "see" the world in the same way (18). This is in accordance with the views of Peter Berger who saw human action as a product of processes of internalization and externalization, and tended to be constructionalistic (19).

The author raises the phenomenon of Sundanese Head tie through scientific studies with qualitative methods. Which according to Creswell inside Qualitative Inquiry \& Research Design-Choosing Among Five Approaches (2007) : "Qualitative research begins with assumptions, a worldview, the possible use of a theoretical lens, and the study of research problems inquiring into the meaning individuals or groups ascribe to a social or human problem"(20).

The approach of this research is through biographical studies, the author tries to analyze narratively from one side of an individual's life, (Czarniawska,2004, p17); "Narrative is understood as a spoken or written text giving an account of an event/action or series of events/actions, chronologically connected" (20), where the cultural symbol in Dedi Mulyadi is seen from scientific binoculars, with the connection of findings - data so that the writer can present it through a social construction framework in the reality of human life. Narrative Research Procedure. This research was conducted on an individual who will be analyzed through narrative exposure from important segments in the life of individual Dedi Mulyadi. Every human being is a communication agent, especially a leader who becomes a public figure in various policy and power owners. Dedi Mulyadi as a leader in an organization political parties of Golongan Karya (GOLKAR) West Java region and former Purwakarta Regency Regent. According to Clandinin and Connelly (2000,p20) : "Narrative inquiry is stories lived and told" (20).

The approach taken by general procedural guidelines, the method of conducting narrative studies does not follow a key-step approach, but is a collection of informal topics. The information obtained for this research study refers to the perpetrators of life which are the main key in this biography study, namely Dedi Mulyadi. Through the informant, the author gets a lot of information about Sundanese Iket. The form of nonverbal communication, namely through cultural symbols, namely iket Sunda as the identity brand of Dedi Mulyadi. In the study of data, Sundanese Iket has a philosophy full of meaning that is implemented in life.

In this study, the authors used Scientific writing guidelines from John W Creswell's book, Second Edition 'Qualitative Inquiry \& Research Design" Choosing Among Five Approaches, Sage Publications, Inc., at Thousand Oaks, California. The guide to this method of research Narrative is on pages 53 to 225. ISBN Number 978-1-41291606-6. (20). The following are the research stages: Data Collection Technique. 1).Access and rapport, 2).Purposeful Sampling Strategy, 3).Forms of Data, 4).Recording Procedures, 5).Field Issues and 6). Storing Data. Data Analysis Technique : 1).Data Management, 2).Reading, 3).Presentation, 4). Classification, 5).Interpretation, and 6).Presentation. Data Validation Techniques. Validation of data is done by analyzing the results of data from several informants, both living witnesses and experts. Namely: Deddy Mulyana (Professor of Communication as well as Professor of Padjadjaran University Bandung), Enjang AS (Sundanese Cultureist and Academician, namely Deputy Dean 1 Faculty Communication and Da'wah of the State Islamic University of Sunan Gunung Djati Bandung), Vega Darwanti (Indonesian Artist) who has collaborated several times with Dedi Mulyadi at cultural events, and Heri Anwar (Head of Tourism and Culture in Purwakarta Regency West Java Province).

\section{RESULTS AND FINDINGS}

For 15 years leading the Purwakarta Regency, Dedi Mulyadi merged with traditional Sundanese clothing. His daily appearance, both official and non-official activities are often different from other regional leaders. His figure in the lead, seemed to break away from the standard rules of protocol dressed as officials in general. His peculiarity uses pangsi clothes and uses Sundanese head tie (iket), called Iket Sunda, describing the integrity of Sundanese humans who are dynamically active so that apart from stereotypes and shadows that Sundanese people are lazy. The tangible, iket can be seen, held, formed, then iket is said to be a product, as Keller shown "A product is anything we can offer to a market for attention, acquisition, use, or consumption that might satisfy a need or want" (16).

Why can a product be associated with a brand ? Because according to the American Marketing Association (AMA), a brand is a "name, term, sign, symbol, or design, or a combination of them, intended to identify the goods and services of one seller or group of sellers and to differentiate them from those of competition." Technically speaking, then, whenever a marketer creates a new name, logo, or symbol for a new product, he or she has created a brand (16), and, A brand is therefore more than a product, because it can have dimensions that differentiate it in some way from other products designed to satisfy the same need. These differences may be rational and tangible - related to product performance of the brand-or more symbolic, emotional, and intangible-related to what the brand represents (16).

Iket (tie) Sunda used by Dedi Mulyadi while leading Purwakarta has a different color ; white, black and black - 
white motifs in Balinese style (or chess), sometimes not forgetting to put 1 (one) frangipani flower stem between the right earlobe with the Sundanese iket. According to Dedi Mulyadi, "the use of Sundanese Iket for me has its own philosophy.." (21), the philosophy in question is The Kasundaan philosophy that is Cing Caringcing Pageuh Kancing, Set Saringset Pageuh Iket (CCPKSSPI), where the philosophy has a noble meaning that can be applied in various fields of activity.

According to Deddy Mulyana, Member of the Editorial Board of newspaper of Pikiran Rakyat (PR) and the Great Teacher of Faculty of Communication, Padjadjaran University Bandung ; "For me, the headband is a symbol of the awakening of Sundanese culture, especially its constructive aspects" (14).

The symbol attached to the figure of Dedi Mulyadi while leading Purwakarta Regency is the Sundanese Iket used. It is like an effort to express the perception that Dedi Mulyadi is proud to be a Sundanese, a leader of Sundanese people with a person who is different from the others, unique, eccentric and seemingly eccentric, so that he is easily recognized. The phenomenon that occurs as a social reality that occurs is interesting to discuss.

The following are the findings on the field regarding Sundanese iket which are always used by Dedi Mulyadi in various activities through more than 6 sides of view : First thing, when someone looks at a figure, of course it will be seen from the appearance individuals who are often used in their daily lives will give an impression to those who see it. The attributes that they use can form their own perceptions for those who often see them so that they become an inspiration in their minds. This is as expressed by Kapferer, - its 'physique'. It is made of a combination of either salient objective features (which immediately come to mind when the brand is quoted in a survey) or emerging ones (17).

There are several opinions regarding the typical appearance of the Former Regent of Purwakarta, Dedi Mulyadi, According to Mochamad Rafe'i - Former Regional Assistant I in the Field of Government Purwakarta Regency (2005 - 2009 period) ; "The head ti used by Dedi Mulyadi shows his identity as a native Sundanese" (3), this is according to what was conveyed by Dedi Mulyadi ; "I was born and grew up in a Sundanese environment, I am proud to be a Sundanese. So that my Sundanese soul is seen in my daily activities" (21).

And according to the local Mass Media Owner, TREND Radio 101,2 FM Purwakarta, Eka Pribadi Toni Putra ; "Dedi Mulyadi, is identical to the head of the Iket Sunda. Seen as Sundanese man, both from the way he dressed, spoke, made a speech using Sundanese, even though in the official event Dedi Mulyadi was his trademark iket, if without iket like not Dedi Mulyadi" (22). This is in line with the opinion of an Indonesian artist, Vega Darwanti who had collaborated several times in cultural events stating that, "The figure of Dedi Mulyadi in my mind is his appearance with Sundanese Iket" (23). Whereas according to the Sundanese Cultureist and Deputy Dean 1 Academic Affairs Faculty of Communication and Da'wah of the State Islamic University (UIN) Sunan Gunung Djati Bandung - West Java, Enjang AS say about Iket as a characteristic that: "Very possible, when the symbol then absorbs (attaches) to another symbol, then it will be the personification of that symbol. And the more he shows in attractions, the ideas embodied in empirical symbols. Symbols - concrete symbols to try to divert abstract symbols. The concrete symbols of Dedi Mulyadi by Sundanese iket are translations of abstract symbols owned by Dedi Mulyadi" (24), because in reality, the use of Sundanese Iket in official activities can be said to violate the rules or break the rules of official protocol, especially when there are refusals from some people, who consider that the Sundanese Iket used by Dedi Mulyadi is similar to Iket Bali (udeng).

This difference can be seen through the following narration : Sundanese iket philosophy in Dedi Mulyadi is ; Cing Caringcing Pageuh Kancing, Set Saringset Pageuh Iket (CCPKSSPI). Cing Caringcing Pageuh Kancing (filosofi feminine), with the pangsi sunda clothing symbol, which means the Glory of Man Is Very Dependent on the Heart. Set Saringset Pageuh Iket (filosofi maskulin) with the symbol of Sundanese Iket, that the Glory of Man Depends on the Mind. So that the Mind and Heart become an inseparable entity..." (21).

While Udeng Bali is : Udeng is a symbol "ngiket manah" (concentration of mind) the source of our five senses ; a) The right curve is higher than the left means more doing good (dharma) than bad (a-dharma), b) The bond in the middle right on the forehead means focusing our mind, c) The upper end symbolizes upright thoughts to worship the Almighty God. Udeng as a complement to Balinese Customary Clothing and worship clothing has a Godhead symbol that unites Tri Murti in a "single" knot; a) The pull of the right end of the cloth symbolizes, Wisnu, b) The pull of the left fabric end symbolizes, Brahma, c) The end of the fabric that is pulled down symbolizes, Siwa (25).

In plain view, Sundanese iket (head tie) used by Dedi Mulyadi is different from Balinese iket (udeng), both different from the motif, how to use even the binding pattern. According to Dedi Mulyadi; "The iket used is different from the head of a typical Balinese Iket or udeng. The Sundanese icon I use is my own work" (21).

Based on the table above it can be concluded that ; Sundanese Iket (Iket Sunda) or Sunda icon is a tangible object, made of quadrilateral cloth and then becomes a triangle shape, then the longest side part (triangular base) rolled almost exhausted then tied to the forehead of the head, the middle edge of the forehead behind the head then knotted and tied back towards the front of the head knotted a little strong on the forehead so as not to fall or sag, with the symmetrical (same) left and right position. While Balinese Iket (Udeng), has a position on the right side of the upper edge higher than the left or top left. This is in accordance with the philosophy of udeng itself.

Iket Sunda (Sundanese Iket), now comes more varied, full of motifs and colors of many color variants. According to Head of Tourism Division - Purwakarta Regency Government, Heri Anwar ; "Sundanese Iket (Iket Sunda) used by Kang Dedi (Dedi Mulyadi) is made of simple material, the folding method is also simple, washed as usual

\section{Published By:}

Blue Eyes Intelligence Engineering

\& Sciences Publication 
with detergent without any special rituals. The color or motif used by Dedi Mulyadi is black and white. If hot weather often uses white iket. If the weather is cold then black iket is used. Since the weather is hot in Purwakarta, white iket often uses it. Sundanese Iket is different from Balinese Iket (udeng)" (26).

Based on some of these opinions, it can be said that Dedi Mulyadi is a Sundanese identity leader, and uses Sundanese iket for more than 15 years, so Sundanese iket for Dedi Mulyadi has become a device and symbol in all his leadership activities. Iket Sunda or Sundanese head tie Dedi Mulyadi has a philosophy Sunda which was written in the book as well as the philosophy became the title of the book is Cing Caringcing Pageuh Kancing, Set Saringset Pageuh Iket Sunda

Table.II

Public Figure Said About Dedi Mulyadi's Ideas

\begin{tabular}{|c|c|c|}
\hline NO & PROMINENT FIGURE'S OPINION & DATA SOURCE \\
\hline 1 & $\begin{array}{l}\text { Prof. Dr. Ing. H Bacharuddin Habibie Jusuf for } \\
\text { the results of the leadership of Dedi Mulyadi stated } \\
\text { that "The Purwakarta Regent Program Is Similar To } \\
\text { Germany (27). }\end{array}$ & $\begin{array}{l}\text { http://studijerman.com/7-alasan-mengapa-jerman- } \\
\text { tergolong-sebagai-negara-maju/ }\end{array}$ \\
\hline 2 & $\begin{array}{l}\text { Dedi is able to integrate culture, innovation, } \\
\text { creativity and collaboration as the core spirit in } \\
\text { building his region (28). }\end{array}$ & $\begin{array}{l}\text { https://www.republika.co.id/berita/nasional/daerah/15/ } \\
\text { 08/14/nt2df5368-ini-alasan-bupati-purwakarta-diundang } \\
\text { pidato-di-markas-pbb }\end{array}$ \\
\hline 3 & $\begin{array}{l}\text { Chairman of the Golkar Party DPP Aburizal } \\
\text { Bakrie assessed, "... the idea of Dedi Mulyadi. there } \\
\text { is no need to doubt ... Dedi Mulyadi is a "farmer" } \\
\text { who consistently cultivates (29). }\end{array}$ & $\begin{array}{l}\text { https://regional.kompas.com/read/2018/05/28/065013 } \\
\text { 21/aburizal-bakrie-adinda-dedi-mulyadi-pantas-menjadi- } \\
\text { pemimpin }\end{array}$ \\
\hline 4 & $\begin{array}{l}\text { Ustadz Yusuf Mansur assessed that the policy } \\
\text { idea of Purwakarta Regent Dedi Mulyadi was } \\
\text { indeed wild and very 'out of the box'. But, he said, } \\
\text { these ideas and policies are now needed in West } \\
\text { Java (30). }\end{array}$ & $\begin{array}{l}\text { https://news.okezone.com/read/2018/02/09/525/18572 } \\
\text { 02/yusuf-mansur-gagasan-dedi-mulyadi-memang-liar- } \\
\text { tapi-dibutuhkan }\end{array}$ \\
\hline 5 & $\begin{array}{l}\text { Finlandia University admire to Dedi Mulyadi's } \\
\text { Concept of Character Education. } \\
\text { Executive Vice President of Finlandia University, } \\
\text { Pasi Kaskinen "... This man is energetic. The } \\
\text { concept of education is in accordance with culture. } \\
\text { Our country is based on our own culture... “ (31). }\end{array}$ & $\begin{array}{l}\text { https://jabar.tribunnews.com/2018/09/13/finlandia- } \\
\text { university-kagumi-konsep-pendidikan-karakter-gagasan- } \\
\text { dedi-mulyadi?page=2 }\end{array}$ \\
\hline
\end{tabular}

Source : Processed by the author, 2019

(CCPKSSPI) ; "Iket Sunda has a place in the head, saringset is interpreted as not loose so it causes oversize in dressing. So by using Sundanese iket on the head, the hair becomes neat and in the end does not block the view. When used headgear, this Sundanese iket is tied not so tight, but enough to protect the head and does not feel pain due to bonding” (32). Sundanese Iket which is used as a simple headwear for simple needs is that the head is not cold and / or enters the wind, causing pain and experiencing interference or obstacles in thinking. In other words, the word iket is Sundanese when combined with a Set Saringset shows the power of healthy thinking using strong logic with the aim that the brain's ability to think must be used properly and correctly and protect the physical condition of the head correctly and maintained. Another reason, the head must be protected because it is the main source in the thinking process so that logic can run normally and balanced (32).

The core philosophy of Sundanese Iket is preparedness, alertness, prudence, policy and justice, and the ability to protect things - very important things: and must be done immediately by men in guarding their homes, villages and further away are the nation and state (32). The opinions of the leaders can be seen on Table.II.
The Head of the Purwakarta Regency National and Political Unity Office, Uus Usna said ; "Dedi Mulyadi is a visionary, there are always ideas and ideas. Advancing Purwakarta is an important point for Dedi Mulyadi. The results can be felt now by the community. So that many tourists come, to meet with Mr. Dedi Mulyadi, see cultural arts or enjoy tours in Purwakarta" (33). And now Purwakarta Regency has become a destination city, both national and international tourists

Iket Sunda is in harmony with its function as a symbol of spirit in thinking and creating, focusing on work which is manifested in various development concepts while leading Purwakarta. "... Sundanese people must be principled on the basis of life, the concept of life, the implementation of the journey of life, the purpose of life, and the attributes of life. So Sundanese humans will be formed as humans who have norms, values, and ethics and aesthetics" (32).

Dedi Mulyadi is a figure who likes to read books from childhood until now. So it is not surprising if Dedi Mulyadi conveyed many ideas as a solution to various problems with the approach of local culture. According Kapferer : This explains why the idea of having a famous character 
represent the brand has become so widespread. The easiest way of creating instant personality is to give the brand a spokesperson or a figurehead, whether real or symbolic (17).

Present ideas represent characters, through the number or variety of ideas (ideas), it will form a person who is easily

\section{Table.III}

Inspirational News From Dedi Mulyadi's Activities

\begin{tabular}{|c|c|c|}
\hline $\mathrm{NO}$ & NEWS TITLE & NEWS LINK \\
\hline 1 & $\begin{array}{l}\text { Dedi Mulyadi's Commitment To Care For } \\
\text { Poor Widows And Orphans (34) }\end{array}$ & $\begin{array}{l}\text { https://news.okezone.com/read/2018/05/28/337/1903 } \\
\text { 464/komitmen-dedi-mulyadi-peduli-janda-miskin-dan- } \\
\text { anak-yatim }\end{array}$ \\
\hline 2 & $\begin{array}{l}\text { Dedi Mulyadi Sprayed the Working Group } \\
\text { Cadres Golongan Karya (GOLKAR) Who Do } \\
\text { Not Care About the Poor Citizens (35) }\end{array}$ & $\begin{array}{l}\text { https://nasional.tempo.co/read/793184/dedi-mulyadi- } \\
\text { semprot-kader-golkar-yang-tak-peduli-dengan-warga- } \\
\text { miskin }\end{array}$ \\
\hline 3 & $\begin{array}{l}\text { Dedi Mulyadi Will Establish Citarum Care } \\
\text { School (36) }\end{array}$ & $\begin{array}{l}\text { https://regional.kompas.com/read/2018/07/01/14424 } \\
\text { 621/dedi-mulyadi-akan-dirikan-sekolah-peduli-citarum }\end{array}$ \\
\hline 4 & $\begin{array}{l}\text { Dedi Mulyadi Asks Candidates for Party } \\
\text { Legislaltif (Candidates) for Work to Door To } \\
\text { Door Groups Go to the People, Don't Serve } \\
\text { Many Ceremonies (37) }\end{array}$ & $\begin{array}{l}\text { http://jabar.tribunnews.com/2018/09/18/dedi- } \\
\text { mulyadi-minta-caleg-partai-golkar-untuk-door-to-door- } \\
\text { datangi-rakyat-jangan-banyak-seremonial }\end{array}$ \\
\hline 5 & $\begin{array}{l}\text { Losing the Election of Governor (Pilgub) } \\
\text { West Java, Kang Dedi Still Help the People in } \\
\text { Karawang (38) }\end{array}$ & $\begin{array}{l}\text { https://tvberita.co.id/index.php/news/nasional/kalah- } \\
\text { di-pilgub-jabar-kang-dedi-tetap-bantu-rakyat-di- } \\
\text { karawang }\end{array}$ \\
\hline 6 & $\begin{array}{l}\text { West Java's People's Glory, Dedi Mulyadi } \\
\text { Gives Access to Ease of Quality Food, } \\
\text { Clothing and Board (39) }\end{array}$ & $\begin{array}{l}\text { https://www.pikiran-rakyat.com/jawa- } \\
\text { barat/2018/06/07/muliakan-rakyat-jabar-dedi-mulyadi- } \\
\text { berikan-akses-kemudahan-pangan-sandang-dan }\end{array}$ \\
\hline
\end{tabular}

\section{Source : Processed by the author, 2019}

Leads as part of the session of human life, where humans are leaders for themselves. But the fate of leading others is determined by the process of life's journey. The character of the leader must have strong principles, and character can be seen through verbal and non-verbal communication activities. According to Kapferer ; "By communicating, it gradually builds up character. The way in which it speaks of its products or services shows what kind of person it would be if it were human (17).

In accordance with his hobby of reading, Dedi Mulyadi has also written many books that contain ideas and thoughts in leadership. One of them is a book entitled Pedaling the Country with Love, Dedi Mulyadi said : "love will give everything best for her lover. Who is our lover? Our beloved is not only a wife, but also a mother, as well as all those who need help" (40). Sundanese people are based on strong intentions say attitude and behavior. Both personally and in groups and in the social life of the Sundanese community (41).

According to Kapferer: There is no cult brand without a brand culture. A brand should have its own culture, from which every product derives. The product is not only a concrete representation of this culture, but also a means of communication. Here culture means the set of values feeding the brand's inspiration. It is the source of the basic principles governing the brand in its outward signs (products and communication (17).

Deddy Mulyana Member of the Editorial Board Newspaper of Pikiran Rakyat and major teachers of Faculty of Communication Sciences, Padjadjaran University brand's aspirational power. The cultural facet refers to the

recognized quickly, both being a discussion of what is done in reality activities or a symbol as a motivational lighter. The figures of Dedi Mulyadi's Inspirational News compiled from various sourcescan be seen on Table III.

Bandung said ; "... One of the reasons often stated is that Indonesians still suffer from low self-syndrome due to being overrun by foreigners for too long. They tend to worship foreign cultures while degrading their own culture..." (14).

Now with the persistent figure of socializing its culture, it becomes an inspiration for other people who are expected to emerge pride in their own culture. Not only glancing and enjoying foreign culture, so that the younger generation is expected to be loyal to the noble values of culture as part of local wisdom.

Online media and social media are the most accessible media for most people. Through the media, the presence of Dedi Mulyadi was widely reported and discussed. On social media, on a Facebook account "Kang Dedi Mulyadi" can be found in the number of followers (followers) above the 10 million figure. This is in accordance with the news that: "Fan Page Kang Dedi Mulyadi on Facebook has a fantastic follower of 10 million. Creating a Kang Dedi fanpage is one of the top 5 figures in Indonesia with the most number offollowers "(1).

This can be seen on the Table IV, which is processed by the author from the actual source of the link as of June 15, 2019. The reason the author takes Top 5 Politician follower data in Indonesia using Facebook sources is based on the results of research in America that; In 2016, Pew found that $79 \%$ of adults who are online in the US used Facebook. Instagram came in second with a distant $32 \%$ score. This year Pew asked a different question. Instead of looking at online adults, they reported data about all US adults. By this metric, Facebook held steady at $68 \%$ of all adults in both 2016 and 2018 (42). 
International Conference on Recents Advancements in Engineering and Technology (ICRAET-18) |15th and 16th March 2019|Siddhartha Institute of Technology \& Sciences, Telangana, India.

Table.IV

Rangking Of The Number Of Followers On The Facebook Media until June 15, 2019

\begin{tabular}{|c|c|c|c|}
\hline $\mathrm{NO}$ & FACEBOOK ACCOUNT & $\mathrm{R}^{{ }^{\text {FOLLOWE }}}$ & LINK SOURCE \\
\hline 1 & $\begin{array}{ccc}\text { Kang } & \text { Dedi } & \text { Mulyadi(43) } \\
@ \text { DediMulyadi1971 } & \\
\end{array}$ & $10,115,349$ & $\begin{array}{l}\text { https://web.facebook.com/DediMulyadi1971/?_r } \\
\text { dc=1\&_rdr }\end{array}$ \\
\hline 2 & $\begin{array}{ll}\text { Prabowo } & \text { Subianto(44) } \\
@ \text { PrabowoSubianto } & \end{array}$ & $9, .902,437$ & $\begin{array}{l}\text { https://web.facebook.com/PrabowoSubianto/?_rd } \\
\text { c=1\&_rdr }\end{array}$ \\
\hline 3 & $\begin{array}{lll}\begin{array}{l}\text { Presiden } \\
\text { @ Jokowi }\end{array} & \text { Joko Widodo(45) } \\
\end{array}$ & $9,661,100$ & https://web.facebook.com/Jokowi/?_rdc=1\&_rdr \\
\hline 4 & $\begin{array}{cc}\text { Sandiaga Salahuddin } & \text { Uno(46) } \\
@ \text { SandiSUno } & \\
\end{array}$ & $2,207,178$ & $\begin{array}{l}\text { https://web.facebook.com/SandiSUno/?_rdc=1\& } \\
\text { _rdr }\end{array}$ \\
\hline 5 & $\begin{array}{cc}\text { Anies } & \text { Baswedan(47) } \\
@ \text { aniesbaswedan } & \end{array}$ & 1.605 .458 & https://web.facebook.com/aniesbaswedan/ \\
\hline
\end{tabular}

\section{Source : Processed by the author, 2019}

Other research results state; Facebook is by far the most popular mobile social networking app in the United States in March 2019, 89.8 percent of U.S. mobile users accessed the mobile app. The company's other mobile social media properties Facebook Messenger and Instagram were ranked second and third with 64.6 and almost 57.9 percent audience reach respectively (48). Based on these, According to Kapferer: "Brands are often at the crux of transactions and exchanges between people." (17)

This indicates the existence of social exchanges or the results of the implementation of consistency in applying the noble values of the Sundanese Iket philosophy in aspects of leadership, as well as the results of activities carried out through verbal and nonverbal communication activities which are the talk and news, causing news curiosity impact or information from the status of the account owner. Sometimes a person becomes a follower because; likes, half likes or dislikes, but always wants to see statuses.

According to Deddy Mulyana Member of the Editorial Board of the Newspaper of Pikiran Rakyat and the great teacher of Faculty of Communication University of Padjadjaran ; "... It is only natural if Dedi Mulyadi as Purwakarta regent won the Pangajén Rumawat Budaya award from Pikiran Rakyat in order to celebrate his 50th anniversary in Bandung recently. Dedi is indeed tireless to lift and maintain Sundanese culture. He did not hesitate to wear Sundanese clothing, including headbands, when delivering a cultural speech at the UN headquarters in New York, United States, last year"(14).

Based on the hard work done by Dedi Mulyadi, aside from the many ideas, ideas, through cultural wrapping, it produces fruit, namely as the owner of the most followers on social media Facebook at the level of leaders and politicians. Sundanese Iket is full of meaning in various aspects of life, now a new trend that is starting to be liked by all circles. Because the use of Sundanese iket has no limitations on age, strata or status. Anyone can use it in various activities.

Kapferer said ; Reflecting the customer is not describing the target; rather, the customer should be reflected as he/she wishes to be seen as a result of using a brand" (17).

The use of Sundanese traditional clothes (pangsi) and Sundanese iket, which are commonly used by Dedi Mulyadi, is used as a rule in Purwakarta Regency, one of which is school children on certain days must wear pangsi clothes and head scarves.

These rules must also be followed by Civil Servants (PNS) in the Purwakarta area, elementary school children, secondary schools, high school and all teachers. So that the traditional Sundanese dress culture becomes a unique sight that occurs on Purwakarta every Tuesday and Wednesday. And now culture is "contagious" to other regions in West Java Province, such as Bandung, Subang, Tasikmalaya. Dedi Mulyadi said : "Now these clothes are also worn by civil servants. In fact, I love pangsi clothes to be a mandatory uniform for students of school children in other areas such as in Bandung. Because if Purwakarta has been used and has been running for a long time " (8). A reflection of Sundanese Iket which is now a trend in society can be seen on Table. V.

In the end, a brand speaks to our self-image. If reflection is a mirror outside the target, then the self image is a mirror of the internal target itself. Through attitude, the essence of the mirror appears, establishing an understanding of oneself. According to Kapferer : 'Finally, a brand speaks to our self-image. If reflection is the target's outward mirror (they are ...), self-image is the target's own internal mirror (I feel, I am ...). Through our attitude towards certain brands, we indeed develop a certain type of inner relationship with ourselves (17).

Dedi Mulyadi who is synonymous with Sundanese culture in carrying out his leadership, often gets opposition from other parties. And Dedi Mulyadi's explained about himself : I am a Muslim and I do not believe mystically. I am realistic in thinking and acting. What I do as a leader in building the region is a strategy so that our city can be heard, seen and visited by others. So that you can tour Purwakarta" (49).

Based on this explanation, it was found that the beliefs he embraced were Islam by holding religious norms and manifested in all their activities. What he did was to remind the culture eroded by the modernization of the times. Culture that must be maintained so as not to be lost in the age. The research on this individual figure that focuses on the attributes of Sundanese head tie worn by Dedi Mulyadi 
as a public leader based on discussion is not only from 6 Kapferer sides but from the results of this study can be from 8 sides. This can be seen in Figure. 1. The prism which the author referred to as the Octagon (Facet 8) Political Brand Identity Dedi Mulyadi.

Table.V

Iket Sunda Becomes a Trend

\begin{tabular}{|c|c|c|}
\hline NO & TITLE & SOURCES NEWS \\
\hline 1 & $\begin{array}{c}\text { Ikat Kepala Khas Purwakarta Laris Manis di } \\
\text { Malaysia (Typical Purwakarta Headbands Hot } \\
\text { Selling Sweet in Malaysia) (50) }\end{array}$ & $\begin{array}{l}\text { https://www.republika.co.id/berita/nasional/pil } \\
\text { kada/15/11/21/ny684m361-ikat-kepala-khas- } \\
\text { purwakarta-laris-manis-di-malaysia }\end{array}$ \\
\hline 2 & $\begin{array}{l}\text { Berkat Dedi Mulyadi Busana Sunda jadi Fashion } \\
\text { Trendsetter (Thanks to Dedi Mulyadi, Sundanese } \\
\text { Clothing is a Fashion Trendsetter) (10) }\end{array}$ & $\begin{array}{c}\text { http://www.rmoljabar.com/read/2015/04/19/83 } \\
\text { 47/Berkat-Dedi-Mulyadi-Busana-Sunda-jadi- } \\
\text { Fashion-Trendsetter- }\end{array}$ \\
\hline 3 & $\begin{array}{r}\text { Kejayaan Pajajaran Dimulai dari Purwakarta } \\
\text { (Pajajaran Glory Starting from Purwakarta) (51) }\end{array}$ & $\begin{array}{c}\text { https://www.kompasiana.com/ibon/55e975958e } \\
\text { 7e619107b3170f/kejayaan-pajajaran-dimulai- } \\
\text { dari-purwakarta?page=all }\end{array}$ \\
\hline 4 & $\begin{array}{c}\text { Kampret Kang Dedi Paling Laku (Kampret Kang } \\
\text { Dedi Most Selling) (52) }\end{array}$ & $\begin{array}{c}\text { http://jabarekspres.com/2018/kampret-kang- } \\
\text { dedi-paling-laku/ }\end{array}$ \\
\hline
\end{tabular}

\section{Source : Processed by the author, 2019}

Based on the discussion of findings in the field, the figure of Dedi Mulyadi as a leader and politician has its own peculiarities. If Kapferer states brand identity through a hexagon prism in the form of a hexagon, then in this study it is known that there are 2 aspects that form the Political Brand Identity, thus forming octagonal prisms that form the octagon. So to form a brand identity for politicians, we can call it "Octagon of Political Brand Identity." The results of the research found, there are two aspects that have not yet existed at Kapferer's The Six Facets Prism Brand Identity, namely aspects of "Standard" and "Professional" as forming "Octagon of Political Brand Identity."

Figure. 1 shows, it can be seen that on the Internal Side (Internalization) illustrates how the figure of Dedi Mulyadi is represented through Sundanese cultural attribute symbols, namely Sundanese Iket which he has used for more than 15 years both in leadership activities and in political activities, so that people or even contestants can easily remember Dedi Mulyadi. Or in other words, Dedi Mulyadi already has a position in the minds of the people.

The Sunda icon used by Dedi Mulyadi has a noble philosophy: Cing Caringcing Pageuh Kancing, Set Saringset Pageuh Iket (CCPKSSPI). Cing Caringcing Pageuh Kancing (feminine philosophy), with the symbol of Pangsi Sunda clothing, which means the Glory of Man Is (masculine philosophy) with the symbol Iket Sunda, that the Glory of Man Depends on the Mind ... "contains wise values for aspects of the field of life through comprehensive institutional, national and state leadership, so that Sundanese Iket is a masculine philosophy, is an integration in thinking so that it can produce a variety of logical creative ideas and in accordance with religious guidelines to be applied in the process and results of optimal performance because according to Dedi Mulyadi: "creative ideas can be present at the behest of nature. The command of nature is through wind, air, fire and water"

Based on the above explanation, it means that as an active, dynamic and humanist human being must be able to Very Dependent on the Heart. Saringset Paget Iket

"read the natural conditions" expressed or implied. A leader must have an advanced mindset, hold on to history and the past, so that he can stare and step into the future better in various aspects of the government.

Dedi Mulyadi was born as a descendant of Sundanese people, in a Sundanese environment and educated in the care of Sundanese people and in the habits of Sundanese people who must be friendly and kind to anyone. Feeling proud to be a Sundanese, instilling Islamic values implemented through a cultural approach. Dedi Mulyadi believes that "pros and cons are common in life, but wisely aimed at a harmonious system. Because God makes a difference, there are men and women, positive and negative, day and night, black and white, like Chinese philosophy, there are Yin and Yang. "(21)

On the external side (Externalization), as a politician and public leader who is known to be close to the people and attached to the Sundanese Iket, there is a term, "if without iket like not Dedi Mulyadi". His treatment in serving the citizens and often dressed in Sundanese became the main attraction for the residents, so that their ideas, attitudes and behavior resulted in the number of followers on Facebook's social media to reach more than 10 million. The highest number of 5 politicians in Indonesia (as of June 15, 2019). The figure of Dedi Mulyadi was not ashamed to use Sundanese clothing while giving a speech at the United Nations (UN) Headquarters in New York, America. So that consistency in culture produces awards in the field of Arts and Culture. Being a trend setter in the use of Sundanese Iket and Sundanese fashion, so besides people call Dedi Mulyadi as a politician, but also as a Sundanese cultural observer. Because while leading Purwakarta Regency, Dedi Mulyadi has succeeded in building a silent city into an active and bustling city through the concept of city governance with a traditional Sundanese concept but based on Modern. 
1. PHYSICAL

\section{Picture.1Octagon from Dedi Mulyadi's Political Identity Brand}

- Appearance of Sundanese, Pangsi and Sundanese Head Tie.

- More than 15 years Using

Sundanese Iket in

everyleadership activity.

- Iket Sundanese icon a symbol

\section{PERSONALITY}

- Has a life philosophy in

Sundanese cosmology

- Living according to Islamic

Guidance

3. CULTURE

- Living in harmony

- Life Must Compound With

Nature

- Pattern of upbringing discipline

SELF IMAGE

- Sundanese Clothing Trendsetter

- Sundanese Can Be Political Popular

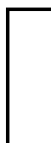

\section{PROFESSION}

- $\quad$ Leader of a Political Party

- Former Regional Leader

- Sundanese culture

- High self Confidence

\section{STANDARD}

- Consistent

- Never give up

- Ambitious

- Hard work

- Discipline

Source : research findings by the author, 2019 
Based on the findings of this study, it is possible to add new motivation to future researchers. With the existence of the Octagon of Political Brand Identity, it can expand the knowledge, that the concept of a hexagonal prism that was originally a tool to analyze the brand identity of a product, can now be used to analyze the brand identity of an individual or a professional, namely by using an octagon or octagon prism. So that it can be called "Octagon Brand Identity (Professional : politicians, economists, doctors and others), through the two latest aspects of the findings of this study, namely :

1). "Standard" aspects for analyzing internal (internal) and 2). "Profession" aspect to analyze the external (external) that relates to other people. Hopefully these findings can be useful for readers and other researchers

\section{CONCLUSION}

Dedi Mulyadi, who is now actively competing in the political field, has developed a political communication strategy through a cultural approach that is explicitly applied in his leadership to build constructive and educative relations patterns.

Dedi Mulyadi organizes career paths in a planned and consistent manner. Dedi Mulyadi already has a position in the minds of the community. The strategy carried out by Dedi Mulyadi is a step that is not easy, when it must maintain consistency by using cultural attributes, namely Sundanese head tie for more than 15 years. Dedi Mulyadi is also always close to the community, especially his concern for the poor, widows, orphans.

As a person born of Sundanese descent, with Sundanese philosophy: honing each other, caring for each other, caring for each other, the figure of Dedi Mulyadi with cultural attributes as a symbol, wants to turn into a superior politician at the National and International level. level. So that the Sundanese who are synonymous with gentleness, creativity, humility, courtesy are important indicators with high bargaining power to be able to exist in the hearts of the people in the National leadership, both in politics and government. And Dedi Mulyadi has proven part of the trip

\section{REFERENCES}

1. Hasibuan IG. Fantastis, Follower Dedi Mulyadi Tembus Angka 10 Juta [Internet]. http://suaraindonesianews.com. 2018 [cited 2019 Apr 25]. Available from: http://suaraindonesia-news.com/fantastis-follower-dedi-

2. Awaliah YR. Budaya Lokal, dari Simbol ke Substansi [Internet]. https://jabar.tribunnews.com. 2013 [cited 2018 Sep 16]. Available from: https://jabar.tribunnews.com/2013/12/23/budaya-lokaldari-simbol-ke-substansi

3. Rafe'i M. Iket Sunda Dedi Mulyadi. Purwakarta; 201AD.

4. Tessar N. Ribuan bedug dan petromak sambut ramadhan di purwakarta [Internet]. www.liputan6.com. 2017 [cited 2019 Jan 3]. Available from: https://www.liputan6.com/news/read/2967385/ribuanbedug-dan-petromak-sambut-ramadhan-di-purwakarta

5. Salam B. Tiga-hal-ini-jadi-refleksi-bupati-dedi-mulyadidi-gua-hira [Internet]. www.merdeka.com. 2017. Available from: https://www.merdeka.com/peristiwa/tiga-hal-ini-jadirefleksi-bupati-dedi-mulyadi-di-gua-hira.html mulyadi-tembus-angka-10-juta/

6. Nugraha I. Melihat-gaya-pakaian-dedi-mulyadi-dansikapnya-yang-anti-protokoler [Internet]. regional.kompas.com. 2018 [cited 2019 Jan 2]. Available from:

https://regional.kompas.com/read/2018/07/17/15164821/ melihat-gaya-pakaian-dedi-mulyadi-dan-sikapnya-yanganti-protokoler

7. Mardiana E. Diberi-iket-oleh-bupati-purwakarta-annakarina-dari-filipina-its-cool [Internet]. news.detik.com 2015 [cited 2019 Jan 23]. Available from: https://news.detik.com/berita/3077205/diberi-iket-olehbupati-purwakarta-anna-karina-dari-filipina-its-cool

8. Salam B. Makna-di-balik-setelan-pangsi-dedi-mulyadi [Internet]. www.merdeka.com. 2016 [cited 2018 Jul 11]. Available from: https://www.merdeka.com/peristiwa/makna-di-baliksetelan-pangsi-dedi-mulyadi.html

9. Ekspres J. Kampret Kang Dedi Paling Laku [Internet] jabarekspres.com. 2018 [cited 2018 Nov 11]. Available from: http://jabarekspres.com/2018/kampret-kang-dedipaling-laku/

10. Jabar R. Berkat-Dedi-Mulyadi-Busana-Sunda-jadiFashion-Trendsetter [Internet]. www.rmoljabar.com 2015 [cited 2018 Sep 9]. Available from: http://www.rmoljabar.com/read/2015/04/19/8347/BerkatDedi-Mulyadi-Busana-Sunda-jadi-Fashion-Trendsetter-

11. Umar DA. Iket Sunda Dedi Mulyadi. Jakarta; 2017.

12. Barnard MLU. Fashion statements: communication and culture [Internet]. https://dspace.lboro.ac.uk/ BARNARD, M., 2011; 2011. Available from: https://dspace.lboro.ac.uk/dspacejspui/bitstream/2134/15122/3/BarnardFashStatements.pd

13. Pich C, Dean D, Punjaisri K. Political brand identity: An examination of the complexities of Conservative brand and internal market engagement during the 2010 UK General Election campaign. J Mark Commun [Internet] 2016 Jan 2;22(1):100-17. Available from: http://www.tandfonline.com/doi/full/10.1080/13527266.2 013.864321

14. Mulyana D. Ikat Kepala. https://www.pikiranrakyat.com. 2016.

15. Distrosunda A roche. Presentasi diklat tentang Iket Sunda Presentasi diklat tentang Iket Sunda [Internet] http://sdm.data.kemdikbud.go.id. 2017 [cited 2018 Nov 8]. Available from: http://sdm.data.kemdikbud.go.id/upload/files/KIS IKET POWERPOINT.pdf

16. Keller KL. 'Building, measuring and managing brand equity' [Internet]. 4th ed. Vol. 6, Journal of Brand Management. 1998. 2 p. Available from: http://link.springer.com/10.1057/bm.1998.57

17. Kapferer JN. The New Strategic Brand Management [Internet]. 4th ed. London: Kogan Page; 2008. 171-197 p. Available from: https://books.google.com.au/books?hl=en \&lr=\&id=8PoIt iB7bicC\&oi=fnd\&pg=PR5\&dq=kapferer+2008+brand\& ots=eyZh-

GoGPA\&sig=Hwil8cuIubSS2D4Usvfw_3hy1Ds

18. Lincoln YS. The Constructivist Credo. The Constructivist Credo. Walnut Creek; 2016. 47-54 p.

19. Kuswarno E. Metode Penelitian Komunikasi. Bandung: Widya Padjadjaran; 2009. $20 \mathrm{p}$

20. Creswell JW, Poth CN. Qualitative Inquiry \& Research Choosing Among Five Approaches. 2nd ed. Shaw LC, Greene K, editors. Thousand Oaks: SAGE Publications; 2007. 53-225 p. 
21. Mulyadi D. Iket Sunda. Purwakarta; 2018.

22. Toni EP. Iket Sunda Dedi Mulyadi. Purwakarta; 2018.

23. Darwanti V. Iket Sunda Dedi Mulyadi. Purwakarta; 2018.

24. Enjang A. Iket Sunda Dedi Mulyadi. Bandung; 2019.

25. Giffar. Udeng dan Maknanya dalam Tradisi Hindu-Bali [Internet]. https://sportourism.id. 2017 [cited 2018 Nov 22]. Available from: https://sportourism.id/history/udeng-dan-maknanyadalam-tradisi-hindu-bali

26. Anwar H. Iket Sunda Dedi Mulyadi. 2019.

27. Prima P. 7 ALASAN MENGAPA JERMAN TERGOLONG SEBAGAI NEGARA MAJU [Internet]. http://studijerman.com. 2017 [cited 2018 Sep 5]. Available from: http://studijerman.com/7-alasanmengapa-jerman-tergolong-sebagai-negara-maju/

28. Winarsih IN. Ini-alasan-bupati-purwakarta-diundangpidato-di-markas-pbb [Internet]. www.republika.co.id. 2015 [cited 2017 May 5]. Available from: https://www.republika.co.id/berita/nasional/daerah/15/08 /14/nt2df5368-ini-alasan-bupati-purwakarta-diundangpidato-di-markas-pbb

29. Nugraha I. aburizal-bakrie-adinda-dedi-mulyadi-pantasmenjadi-pemimpin [Internet]. regional.kompas.com. 2018 [cited 2018 Jun 11]. Available from: https://regional.kompas.com/read/2018/05/28/06501321/ aburizal-bakrie-adinda-dedi-mulyadi-pantas-menjadipemimpin

30. Mulyana. yusuf-mansur-gagasan-dedi-mulyadi-memangliar-tapi-dibutuhkan [Internet]. news.okezone.com. 2018 [cited 2018 Oct 22]. Available from: https://news.okezone.com/read/2018/02/09/525/1857202/ yusuf-mansur-gagasan-dedi-mulyadi-memang-liar-tapidibutuhkan

31. Haryanto. finlandia-university-kagumi-konseppendidikan-karakter-gagasan-dedi-mulyadi [Internet] jabar.tribunnews.com. 2018 [cited 2018 Nov 7]. Available https://jabar.tribunnews.com/2018/09/13/finlandiauniversity-kagumi-konsep-pendidikan-karakter-gagasandedi-mulyadi?page $=2$

32. Kasupardi E, Sudrajat U. Cing Caringcing Pageuh Kancing, Set Saringset Pageuh Iket (CCPKSSPI) Purwakarta: Trinada; 2014.

33. Usna U. Iket Sunda Dedi Mulyadi. 2018.

34. Wijayakusuma. komitmen-dedi-mulyadi-peduli-jandamiskin-dan-anak-yatim [Internet]. news.okezone.com. 2018 [cited 2018 Oct 22]. Available from: https://news.okezone.com/read/2018/05/28/337/1903464/ komitmen-dedi-mulyadi-peduli-janda-miskin-dan-anakyatim

35. Tempo.co. dedi-mulyadi-semprot-kader-golkar-yang-takpeduli-dengan-warga-miskin [Internet] nasional.tempo.co. 2016 [cited 2018 Oct 22]. Available from: https://nasional.tempo.co/read/793184/dedimulyadi-semprot-kader-golkar-yang-tak-peduli-denganwarga-miskin

36. Nugraha I. dedi-mulyadi-akan-dirikan-sekolah-pedulicitarum [Internet]. regional.kompas.com. 2018 [cited 2018 Oct 22]. Available from: https://regional.kompas.com/read/2018/07/01/14424621/ dedi-mulyadi-akan-dirikan-sekolah-peduli-citarum

37. Abdussalam S. dedi-mulyadi-minta-caleg-partai-golkaruntuk-door-to-door-datangi-rakyat-jangan-banyakseremonial [Internet]. jabar.tribunnews.com. 2018 [cited 2018 Oct 24]. Available from: https://jabar.tribunnews.com/2018/09/18/dedi-mulyadiminta-caleg-partai-golkar-untuk-door-to-door-datangirakyat-jangan-banyak-seremonial

38. Dej. kalah-di-pilgub-jabar-kang-dedi-tetap-bantu-rakyatdi-karawang [Internet]. tvberita.co.id. 2018 [cited 2018
Oct 25]. Available from: https://tvberita.co.id/news/regional/kalah-di-pilgub-jabarkang-dedi-tetap-bantu-rakyat-di-karawang/

39. PR. muliakan-rakyat-jabar-dedi-mulyadi-berikan-akseskemudahan-pangan-sandang-dan [Internet] www.pikiran-rakyat.com. 2018 [cited 2018 Oct 26]. Available from: https://www.pikiran-rakyat.com/jawabarat/2018/06/07/muliakan-rakyat-jabar-dedi-mulyadiberikan-akses-kemudahan-pangan-sandang-dan

40. Mulyadi D. Mengayuh Negeri dengan Cinta. Bandung: Simbiosa Rekatama Media; 2017.

41. Kasupardi E, Sudrajat U. Adab Sunda. Purwakarta; 2016. $131-138 \mathrm{p}$.

42. Murnane K. Which Social Media Platform Is The Mos Popular In The US? [Internet]. https://www.forbes.com. 2018 [cited 2019 Jan 11]. Available from: https://www.forbes.com/sites/kevinmurnane/2018/03/03/ which-social-media-platform-is-the-most-popular-in-theus/\#5249aef81e4e

43. Mulyadi D. Kang Dedi Mulyadi [Internet]. web.facebook.com. 2019 [cited 2019 Jun 15]. Available from:

https://web.facebook.com/DediMulyadi1971/?_rdc=1\&_ rdr

44. Subianto P. Prabowo Subianto [Internet]. web.facebook.com. 2019 [cited 2019 Jun 15]. Available from:

https://web.facebook.com/PrabowoSubianto/?_rdc=1\&_r $\mathrm{dr}$

45. Widodo J. Presiden Joko Widodo [Internet]. web.facebook.com. 2019 [cited 2019 Jun 15]. Available from: https://web.facebook.com/Jokowi/?_rdc=1\&_rdr

46. Uno SS. Sandiaga Salahuddin Uno [Internet]. web.facebook.com. 2019 [cited 2019 Jun 15]. Available from:

https://web.facebook.com/SandiSUno/?_rdc=1\&_rdr

47. Baswedan A. Anies Baswedan [Internet]. web.facebook.com. 2019 [cited 2019 Jun 15]. Available from: https://web.facebook.com/aniesbaswedan/

48. Statista. Most popular mobile social networking apps in the United States as of March 2019, by reach [Internet]. https://www.statista.com. 2019 [cited 2019 Jun 14]. Available from: https://www.statista.com/statistics/579334/most-popularus-social-networking-apps-ranked-by-reach/

49. Mulyadi D. Kepemimpinan Dedi Mulyadi. Purwakarta 2018.

50. Winarsih IN. Ikat Kepala Khas Purwakarta Laris Manis di Malaysia [Internet]. https://www.republika.co.id. 2015 [cited 2018 Jan 18]. Available from https://www.republika.co.id/berita/nasional/pilkada/15/1 1/21/ny684m361-ikat-kepala-khas-purwakarta-larismanis-di-malaysia

51. Hidayat I. kejayaan-pajajaran-dimulai-dari-purwakarta [Internet]. www.kompasiana.com. 2015 [cited 2018 Dec 12]. Available from: https://www.kompasiana.com/ibon/55e975958e7e619107 b3170f/kejayaan-pajajaran-dimulai-daripurwakarta?page $=$ all

52. Ekspres J. Kampret Kang Dedi Paling Laku [Internet] jabarekspres.com. 2018 [cited 2018 Oct 3]. Available from: http://jabarekspres.com/2018/kampret-kang-dedipaling-laku/ 


\section{AUTHORS PROFILE}

Rina Nurhayati, Born in Bandung, West Java Indonesia on February 12, 1977. Email address ; rina17004@mail.unpad.ac.id. WA: +6281912590377. As a Doctoral Program Student in 2017 and is currently completing a Dissertation research to get a Doctorate in the Faculty of Communication Sciences, Padjadjaran University, Bandung. Has completed the Masters Program from the Consultation of Communication Science, Bandung Islamic University in 2013 and completed the Bachelor Program in the Faculty of Communication Sciences, Bandung Islamic University in 2000. Served as Deputy Chairperson of Academic Affairs, STIES Indonesia Purwakarta, West Java. Teaching courses: 1. Public Relations, 2. Business Communication, 3. Marketing Communication, 4. Lobby and Negotiation, 5. Entrepreneurship, 6. Leadership and Decision Making Theory, and Actively participating in International and National seminars.Getting Award: 1. As the Best Lecturer in 2018 at STIES Indonesia Purwakarta, West Java, 2. As a Copyright Holder (HAKI) from the Ministry of Law and Human Rights Republic of Indonesia, Type of Creation: Writing (Article), Title of Creation: Brand Equity Of STIE Syari'ah Darul Ulum Purwakarta - Registration number: 000119245, in 2018, 3. 2017 Lecturer Certification Recipients from the Ministry of Religion of the Republic of Indonesia in 2017, 4. As Finalists of Best Paper on Social Sciences and Communication Category at the International Research Conference on Higher Education (IRCHE) December E. Excellence Excellence In Research Award on December 5, 2015 in Subic Bay, Philippines.

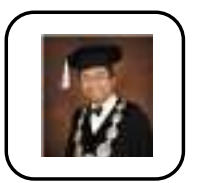

Prof. Dr. H. Engkus Kuswarno, M.S. Born in Garut, West Java - Indonesia on November 17, 1963. He lives in Bandung 40286. A Muslim. Served as Professor at the Faculty of Communication Sciences, Padjadjaran University, Bandung. His last education was a Doctorate in Communication Management, 2004, at the Unpad Postgraduate Program. Title of Dissertation: "Symbolic World of Beggars in Bandung City: Study of Social Construction and Communication Management of Beggars in the City of Bandung". Master of Science in Development-Agriculture and Rural Communication Science, graduated in 1993 at Bogor Agricultural University. Title of Thesis: "Relationship between Characteristics of Respondents and the Use of Radio and Television in the Community of Padasuka Village, Cibinong District, Cianjur Regency, West Java". And the Bachelor's Degree in Communication Science, won in 1987, Padjadjaran University Bandung, Thesis Title: "The Democratic Relationship of Parental Leadership with Openness to the Attitudes and Behavior of Children to Communicate". The awards that have been achieved are: I. Exemplary Lecturer II Unpad Faculty of Communication Sciences, $1994 / 1995$ 2. Second best researcher at Padjadjaran University, 1996/1997 3. Graduated cum laude Doctoral Program, 2004 4. Lecturer with Achievement I Fikom Unpad, in 2008 5. Unpad Achievement Lecturer II, 2008 6. Charter of Honor of the President of the Republic of Indonesia (Republic of Indonesia Presidential Decree no. 62, 6 August 2012): Satyalancana Karyasatya XX year 7. Charter of Unpad Chancellor Award: Satya Karya Bhakti Class II, September 112009 8. Unpad Chancellor Award Charter: Satya Karya Bhakti Class I, Sept. 11, 2014 9. Has Scientific Work Copyright Ownership Certificate - Book.

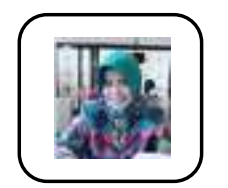

Prof. Dr. Hj. Dra. Neni Yulianita, MS. Born in Cirebon, West Java - Indonesia on July 23, 1958. Served as Professor at the Faculty of Communication Sciences, Bandung Islamic University. Expertise in the fields of Communication, Public Relations, and Corporate Social Responsibility. Lecturers: 1. Public Relations, 2. Introduction to Communication Studies, 3. Communication Theory, 4. Mass Communication, 5. Public Relations Audit, 6. Qualitative Communication Research Methodology (MPK), 7. Personality and Leadership, 8. Kapita Selekta Public Relations, 9. Management and Ethics of Business Communication, 10. Reputation Management Strategy, 11. Political Marketing. Received a Doctorate in 2001 at Padjadjaran University, Bandung, obtained a Master of Science Degree at Padjadjaran University Bandung in 1991 and completed a Bachelor's program at Padjadjaran University Bandung in 1983. Here are just a few Scientific Writings that have beenproduced from many others; 1 . Look at the Practice of "PseudoEvents" in the Public Relations Perspective Environment in the Environmental Communication Book: Management, Social Empowerment, media and CSR. First Print of 2014. Publisher: Faculty of Communication Sciences, Bandung Islamic University in collaboration with Litera Books,
Yogyakarta, 2. "Perpesi and Public Opinion about West Java Traffic Police Image" in the Proceedings of the National Seminar on Research and PKM: Social, Economic and Humanities. Volume 4, No. 1 of 2014. Publisher: University Publishing Center (P2U-LPPM), Bandung, 3. "Negotiation and Lobbying Training for SME Members to Support Business Success" in the Proceedings of the National Seminar on Research and PKM: Social, Economic and Humanities. Volume 4, No.1 of 2014. Publishers: University Publishing Center (P2U-LPPM), Bandung, 4. "Reputation Impact for Indonesian Leaders" in the Future of Communication, Indonesia's Future: Pro-People's Leadership. 2014. Jakarta: Indonesian Bachelor of Communication Association (ISKI), 5. "Online PR activities in West Java Universities" in the Proceeding of the National Political Communication Conference. In 2014. Publisher of Communication Science Study Program Universitas Brawijaya, Malang, 6. "Optimizing the Usage of Professional Social Media for Public Relations (Study in Three Private Universities in West Java Indonesia)". 2015. Proceedings MIPERS 2015 MalaysiaIndonesia Postgraduate Social, Economic, Scince, and Education Research Seminar. Jontly Organized by: Widyatama University, Selangor University, and Indonesian College of Economics. 